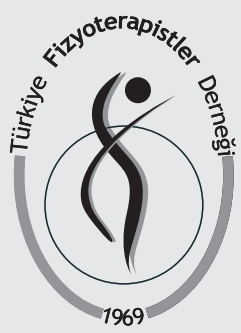

ISSN: $2651-4451 \cdot e-I S S N: 2651-446 X$

\section{Turkish Journal of Physiotherapy and Rehabilitation}

$202031(2) 180-187$

Demet KARABULUT, MSc, PT Şebnem AVCl, PhD, $P T^{2}$

\title{
RELATIONSHIP BETWEEN SLEEP PROBLEMS AND GROSS MOTOR FUNCTION IN CHILDREN WITH CEREBRAL PALSY AND INVESTIGATION OF THEIR PARENTS' QUALITY OF LIFE
}

\section{ORIGINAL ARTICLE}

\section{ABSTRACT}

Purpose: Sleep problems commonly seen in children with cerebral palsy (CP) adversely affect daily living activities and treatment participation. The study aimed to investigate the relationship between sleep problems and gross motor function levels in children with spastic CP and to determine parents' quality of life (QOL).

Methods: Sixty children with spastic CP and 60 typically developing children between the ages of 4 and 12 years and their parents were enrolled in the study. After obtaining demographic data, Gross Motor Function Classification System (GMFCS) was used to determine motor function levels. International Classification of Diseases-10 was used for cognitive function. Children's Sleeping Habits Questionnaire measured children's sleeping habits. The Nottingham Health Profile was used to evaluate parents' QOL.

Results: Fifty-two (86.7\%) children with $\mathrm{CP}$ had sleep disorders. Sleep disturbance values were significantly higher in the CP group than the controls ( $52.7 \pm 7.6$ vs $41.5 \pm 8.01$, respectively), $p=0.001$. There was no significant difference between GMFCS levels and sleep disorders in children with CP $(p>0.05)$ except morning fatigue $(p=0.028)$. There was no difference between cognition, medication use, and sleep problems ( $p>0.05)$. Parents' $Q O L$ was found to be worse in the CP group $(p=0.001)$.

Conclusion: Rate of sleep disorders in children with CP was higher than controls. Their mothers' QOL values were found to be worse. Conditions that may be associated with sleep disorders in children with CP and their parents' conditions need to be better identified and screened.

Key Words: Cerebral Palsy; Gross Motor Function; Parents, Quality of Life; Sleep Disorders.

\section{SEREBRAL PALSILI ÇOCUKLARIN UYKU PROBLEMLERI VE KABA MOTOR FONKSIYON ILIŞKISI VE EBEVEYNLERININ YAŞAM KALITESININ INCELENMESi}

1 Özel Ilgim Special Education and Rehabilitation Center, Düzce, Turkey.

2 Bolu Abant Izzet Baysal University, Faculty of Health Sciences, Department of Physical Therapy and Rehabilitation, Bolu, Turkey.

Correspondence (iletişim):

Sebnem AVCl, PhD, PT Bolu Abant Izzet Baysal University, Faculty of Health Sciences, Department of Physical Therapy and Rehabilitation,

14030 Gölköy Campus, Bolu, Turkey. Phone: +90-374-254 1000 ext. 4137

E-mail: avci_s@ibu.edu.tr ORCID ID: 0000-0003-3712-0551

Demet KARABULUT

E-mail:dg.karabulut@gmail.com ORCID ID: 0000-0002-0467-6767

Received: 04.03.2019 (Geliş Tarihi) Accepted: 11.09.2019 (Kabul Tarihi)

\section{(c)) BY - NC}

Content of this journal is licensed under a Creative Commons Attribution-NonCommercial 4.0 International License.

\section{ARASTTIRMA MAKALESi}

ÖZ

Amaç: Serebral palsili (SP) çocuklarda yaygın olan uyku problemleri, günlük yaşam aktivitelerini ve tedaviye katılımı olumsuz etkilemektedir. Çalıșmanın amacı, spastik SP'li çocuklarda uyku problemleriyle kaba motor fonksiyon seviyeleri arasındaki ilişkiyi ve ebeveynlerin yaşam kalitelerini araştırmak olarak belirlendi.

Yöntem: Çalışmaya, 4-12 yaş aralığında 60 spastik SP'li ve 60 tipik gelişen çocuk, ebeveynleri ile birlikte dahil edildi. Demografik verilerin alınmasının ardından motor fonksiyon seviyelerini belirlemek için Kaba Motor Fonksiyon Sınıflama Sistemi (KMFSS) kullanıldı. Çocukların uyku alışkanlıkları Çocuk Uyku Alışkanlıkları Anketi ile ölçüldü. Kognitif fonksiyonlar için Uluslararası Hastalıklar Sınıflaması-10 kullanıldı. Ebeveynlerin yaşam kalitesi algıları Nottingham Sağılı Profili ile değerlendirildi.

Sonuçlar: Elli iki (\% 86,7) SP'li çocukta uyku bozuklukları tespit edildi. SP'li grubun uyku bozukluğu değerleri kontrol grubuna göre anlamlı şekilde yüksek bulundu $(52,7 \pm 7,6$ ve $41,5 \pm 8,01), p=0,001$. SP'li çocukların KMFSS seviyeleri ve uyku bozuklukları arasında sabah yorgunluğu dışında $(p=0.028)$ anlamlı farklılık yoktu ( $\mathrm{p}>0.05$ ). Kognitif durum, ilaç kullanımı ve uyku bozuklukları arasında fark yoktu ( $p>0.05)$. SP grubundaki ebeveynlerin yaşam kalitesi algılarının daha kötü olduğu bulundu $(p=0,001)$.

Tartışma: Çalışmamız SP'li çocukların uyku bozukluğu oranının kontrol grubundan daha yüksek olduğunu gösterdi. Bu çocukların ebeveynlerinin yașam kalitesi değerlerinin daha kötü olduğu bulundu. SP'li çocuklarda uyku bozuklukları ile ilişkili olabilecek durumların ve ebeveynlerin durumlarının daha iyi tanımlanmasına ve taranmasına ihtiyaç vardır.

Anahtar Kelimeler: Serebral Palsi; Kaba Motor Fonksiyon; Ebeveyn; Yaşam Kalitesi; Uyku Bozuklukları. 


\section{INTRODUCTION}

Children with cerebral palsy (CP) have a higher prevalence of sleep disorders when compared to children without chronic health conditions (1). It is estimated that $13-85 \%$ of such children are afflicted with clinically significant sleep disorders (2). Sleep may be affected by many factors that are common in CP. Muscle spasms, other forms of musculoskeletal pain and the decreased ability to change body position during the night may all contribute to sleep difficulties and are related to the primary motor impairment (1).

Earlier studies have shown that over $35 \%$ of cases applying to a neuropsychiatric center for their sleep problems are children with developmental disorders, epilepsy, brain damage, or similar neurologic impairments. Among children with mental developmental failure and brain damage, certain deviances in the normal sleep cycle are measured to detect sleep problems due to the irregular secretion of hormones arising from the altered perception of light (3).

In children with $\mathrm{CP}$, there is a higher prevalence of initiation and maintenance of sleep, sleep-wake transition disorders, and excessive sleepiness during the day and arousal (1). Children with CP are likely to have apnea or hypopnea during each hour of sleep due to the aspiration triggered by the limited change in body position, hypersalivation, macroglossia, and gastroesophageal reflux $(2,3)$. Such sleep disorders adversely affect daily activities and school performance of children with $\mathrm{CP}$ in the development age. Due to the changes in the muscle tone of children with $\mathrm{CP}$, several problems occur in respiratory muscles resulting in abnormal upper airway control, which then induce sleep disorders $(4,5)$. Failure in having a good night sleep adversely impacts the life quality of the child and significant behavioral problems may impede the rehabilitation process as well $(5,6)$.

Gross motor function level in children with $C P$ is an important determinant of quality of life (QOL) (7). The effects of gross motor function limitation, activity limitations (8), mobility, and functional independence (9) are also seen in children with CP. On the other hand, typically developing children and adolescents have also been reported to have sleep problems. According to the literature, these problems are sleepwalking, nightmares, talking during sleep, snoring, obstructive sleep apnea (OSA), unconscious waking, wetting, delayed sleep phase disorder (10), difficulty in falling asleep, difficulty in waking up in the morning, and frequent and unreasonable waking at night (11).

Based on the literature, the presence of sleep disorders even in children with typical development raised the question of which extent sleep disorders would occur in children with physical disabilities. The second question of the study was about children's parents. The altered pattern of sleep in individuals with CP directly affects parents' physical and emotional well-being (12). The disruption of standard sleep patterns may have an enormous impact upon the interactive and cognitive skills of the children with $\mathrm{CP}$, adversely affect their QOL and interfere with the standard sleeping patterns of siblings and parents (13). Since mothers are the primary caregivers of the child, we aimed to investigate whether their perception of the QOL was affected by their kids' sleep problems.

\section{METHODS}

This cross-sectional study was conducted between January 2013 and August 2014. Upon receiving the approval from the Ethics Committee of Bolu Abant İzzet Baysal University (Approval Date: 20.12.2012 and Approval Number: 2012/244), patients' files of 150 children with CP aged 4-12 years under the rehabilitation service in a special education and rehabilitation center in the city of Düzce, Turkey, were accessed. Among these children, parents of 70 spastic children with $\mathrm{CP}$ matched our criteria were interviewed. The children with spastic CP were included in the study because of the higher number of children in this type generally in the specialized education centers. Inclusion criteria were being an age range between 4 and 12 years, diagnosed with spastic CP by a pediatric neurologist based on international CP criteria (14), and undergoing rehabilitation in a special education and rehabilitation center. Children whose mothers could not be reached $(n=6)$ and who did not belong to the identified age range $(n=4)$ were excluded from the study. 
The CP group consisted of parents and their children with spastic CP $(n=60)$ who provided a signed informed consent form to participate in the study. Sixty age-matched children with typical development, and their parents were served as the control group. Children in the control group consisted of close relatives of those in the $\mathrm{CP}$ group. The children in the control group were not siblings of the CP group, so the mothers were not the same. Inclusion criteria for controls were aged between 4 and 12 years, having no orthopedic, chronic, respiratory, psychiatric or neurologic disease, and being volunteered for the participation in the study. Written informed consents were collected from all parent participants and children who could sign. The mothers who were the primary caregivers fulfilled all items in the questionnaires.

Within the scope of this study, the demographic features of children were collected. The presence of the use of medications was recorded. Gross motor function levels were examined within the context of the Gross Motor Function Classification System (GMFCS). The GMFCS is a classification system developed for children with CP by Palisino et al. The level I means the least effect on motor function for a child with $\mathrm{CP}$, while level $\mathrm{V}$ refers to severe involvement. Level I is the most independent level in motor function, while level $\mathrm{V}$ is the least independent (15). Turkish validity was performed by El et al. (16).

Cognitive function of children was measured using a form completed by the parents. The original form was accessed from SPARCLE (The Study of Participation of Children with Cerebral Palsy Living in Europe) Project. Cognitive function of children was measured using ICD-10 (International Classification of Diseases-10). According to this evaluation, learning disability is defined as mild in children with a cognitive function 50 to 70 and severe if it is less than 50 (17).

In this study, children's sleep habits were evaluated via the Children's Sleep Habits Questionnaire (CSHQ) completed by their parents. The CSHQ, created by Owens et al., is a screening instrument for children based on clinical symptom presentations of common sleep disorders, and is a 45-item parental questionnaire (18). This questionnaire basically queries four sleep parameters, but there are several subscales of these parameters. The main domains are bedtime, sleep behavior, waking during the night, and morning wake-up. Sub-parameters of sleep disorders consist of items such as difficulty in falling into sleep, snoring, nightly wake-ups, OSA, asking for the parent when waking up at night, morning fatigue, and resistance to sleep and feeling discomfort during sleep. Test-retest reliability of the test was acceptable (range 0.62-0.79). The result of the test is given as a total score. A cut-off total CSHQ score of 41 identifies children with a clinical sleep problem with a sensitivity of 0.80 and specificity of 0.72 . It is a three-point scale which is expected to be marked the most appropriate one as "usually, sometimes and rarely" (18). In our study, the mean sleep scores of the children were given for both groups. In addition, children who scored 41 and above from the questionnaire were presented as a percentage of all participants in both groups. Fiş et al. performed Turkish validity study of the questionnaire. It is a valid and reliable tool for screening and evaluating sleep problems and habits in Turkish children (19).

The QOL of parents was analyzed using the Nottingham Health Profile (NHP). The NHP is a 38-item yes/no questionnaire consisting of six subscales: physical mobility, social isolation, sleep, pain, emotional reactions, and energy (20). This survey was preferred because it reliably examines the general anxiety, stress expression, and life status in the general adult population. In this questionnaire, the higher score identifies the worse QOL (21).

All of the evaluation parameters were applied to the children in the control group, excluding GMFCS and cognition. Control group's parents' data were obtained with NHP as well. All permissions were obtained for the evaluation tools, and Turkish versions of the tools were used in the study.

\section{Statistical Analyses}

According to the reference study (22), the CSHQ results had a large effect size $(d=0.757)$. Assuming we could achieve a lower effect size level ( $d=0.500)$, a power analysis was performed before the study. Accordingly, inclusion of at least 102 participants (51 CP children and 51 controls) would result in $80 \%$ 
Table 1: Characteristics of the Participants.

\begin{tabular}{|l|c|c|c|}
\hline \multirow{2}{*}{ Variables } & $\begin{array}{c}\text { CP Group } \\
(\mathbf{n = 6 0 )}\end{array}$ & $\begin{array}{c}\text { Control Group } \\
(\mathbf{n = 6 0 )}\end{array}$ & $\mathbf{2}$ \\
\cline { 2 - 3 } & Mean \pm SD & Mean \pm SD & \\
\hline Age (years) & $8.30 \pm 3.15$ & $7.95 \pm 2.76$ & 0.953 \\
\hline Weight (cm) & $119.43 \pm 24.25$ & $131.13 \pm 16.84$ & $\mathbf{0 . 0 0 4}^{*}$ \\
\hline Geight (kg) & $24.56 \pm 1.28$ & $30.13 \pm 1.10$ & $\mathbf{0 . 0 0 1}^{*}$ \\
\hline
\end{tabular}

${ }^{*} \mathrm{p}<0.05$.

power with 95\% confidence interval. All statistical analyses were performed using SPSS 24.0 (IBM SPSS Statistics 24 software, IBM Corp, Armonk, NY, USA). While the measured scores of cases were expressed is mean and standard deviations, age groups and extremity distributions were expressed as frequencies and percentages (\%). The difference of groups was assessed using Chisquare test (the difference between sleep problems and GMFCS levels was analyzed using Chi-square test). Mann-Whitney $U$ test was used to determine the difference in parents' QOL. In addition, the relationships between continuous variables were analyzed using Spearman's correlation analysis. Statistical significance level was accepted as $\mathrm{p}<0.05$.

\section{RESULTS}

The study was conducted a total of 60 spastic CP cases within a mean age of $8.30 \pm 3.15$ years. Twenty-nine $(48.3 \%)$ of them were females, while 31 (51.7\%) were males. Sixty sex-matched children with typical development with a mean age of $7.95 \pm 2.76$ years were included in the study as controls. The demographic and clinical characteristics of the subjects are presented in Table 1. There was no significant difference in age and gender between the $\mathrm{CP}$ and control groups ( $p>0.05)$.

The majority of cases exhibited clinically severe degrees of motor function. Based on extremity distributions 13 children (21.7\%) were hemiparetic ( $n=9$ for GMFCS level I, $n=1$ for GMFCS level II, $n=1$ for GMFCS level III, and $n=2$ for GMFCS level V), 19 children $(31.7 \%)$ were diplegic $(n=2$ for GMFCS level I, $n=6$ for GMFCS level II, $n=7$ for GMFCS level III, $n=3$ GMFCS for level IV, and $n=1$ GMFCS for level $V)$, and 28 children (46.6\%) were quadriplegic $(n=1$ for GMFCS level III, $n=5$ for GMFCS level IV, and $\mathrm{n}=22$ for GMFCS level V). There were 11 children (18.3\%) at GMFCS level I, seven children (11.7\%) at GMFCS level II, nine children (15\%) at GMFCS level III, eight children (13.3\%) at GMFCS level IV, and 25 children (41.7\%) at GMFCS level V.

In this study, CSHQ total score of the CP group was found as $52.7 \pm 7.6$. Abnormal CSHQ total sleep score was obtained in $86.7 \%(n=52)$ of the children in the CP group.

Among those 52 children with sleep problems, the

Table 2: Sleep Scores and the Distribution of Sleep Problems Based on Gross Motor Function Classification System Levels.

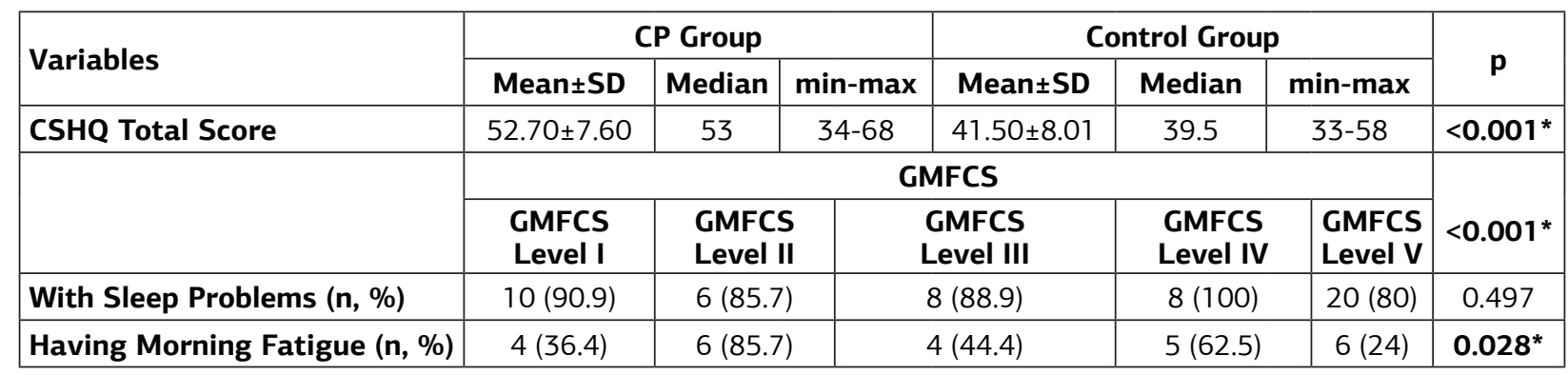

*p<0.05, GMFCS: Gross Motor Function Classification System, CSHQ: Children's Sleep Habits Questionnaire. 
Table 3: Comparison of Parents' Quality of life in Both Groups.

\begin{tabular}{|c|c|c|c|c|c|}
\hline \multirow[b]{2}{*}{ Variables } & \multicolumn{2}{|c|}{ CP Group } & \multicolumn{2}{|c|}{ Control Group } & \multirow[b]{2}{*}{$\mathbf{p}$} \\
\hline & Median & $\begin{array}{c}\min _{(n=60)} \\
\end{array}$ & Median & $\underset{(n=60)}{\min -\max }$ & \\
\hline NHP Total Score & 119.54 & $0-499.72$ & 52.37 & $0-462.90$ & $<0.001^{*}$ \\
\hline Pain & 8.96 & $0-100$ & 7.39 & $0-100$ & 0.155 \\
\hline Emotional Reactions & 22.48 & $0-100$ & 0.00 & $0-100$ & $<0.001^{*}$ \\
\hline Social Isolation & 22.01 & $0-100$ & 0.00 & $0-55.46$ & $<0.001^{*}$ \\
\hline Physical Mobility & 0.00 & $0-41.86$ & 11.37 & $0-43.90$ & $0.001^{*}$ \\
\hline Energy Level & 36.80 & $0-100$ & 0.00 & $0-100$ & $0.028^{*}$ \\
\hline Sleep & 12.57 & $0-77.63$ & 6.28 & $0-77.63$ & 0.417 \\
\hline
\end{tabular}

${ }^{*} \mathrm{p}<0.05$. CP: Cerebral Palsy, NHP: Nottingham Health Profile.

most common sleep disorder was asking for the parent at night with a rate of $73.3 \%$ and waking up at night with a rate of $60 \%$, falling asleep disorder with a rate of $50 \%$, restlessness in sleep with a rate of $56.7 \%$, and morning fatigue with a rate of $41.7 \%$. Control group's total CSHQ score was $41.5 \pm 8.01$. We found that 21 of 60 children with typical development (35\%) had sleep problems. The rates of sleep disorders in typically developing children were as follows: waking up at night was $21.7 \%$, asking for parent was $20 \%$, and resistance to sleep was $20 \%$.

In the comparison of sleep problems, the CP group showed worse total scores than the controls $(p<0.001)$ (Table 2). Upon analyzing the subparameters, there was a significant difference in morning fatigue parameter and motor function level of the CP group ( $p=0.028)$ (Table 2). The majority of children at GMFCS level II and V were experiencing morning fatigue.

No significant difference was found between the GMFCS level of children and sleep disorders score ( $p>0.05)$ (Table 2). This result was approved with Spearman's correlation analysis as well $(r=-0.092$, $\mathrm{p}=0.487$ ).

In the CP group, 18 children had a normal cognitive function (Intelligence Quotient, IQ>70). Fifteen of them experienced sleep problems (28.8\%). Fourteen children had mild cognitive impairment $(50<\mathrm{IQ}<70)$ and 11 of them $(21.2 \%)$ had sleep problems. In addition, 28 children had severe cognitive impairment $(\mathrm{IQ}<50)$, and 26 of them (50\%) had sleep problems. Twenty-two children with CP were taking medications. The $31.6 \%$ of children with sleep problems $(n=19)$ were the ones who were taking medications. We did not find any significant differences in medication use, cognitive function, and sleep problems ( $p>0.05$ ).

According to the NHP data, the median score of parents' perceived QOL in the CP group was 119.54. The most affected sub-parameters were emotional reactions, social isolation, physical mobility, and energy. Parents in the control group showed better scores in NHP than the parents in the CP group $(p=0.001)$ (Table 3$)$. There was no statistically significant difference between NHP scores of mothers of CP group with or without sleep problems (CP with sleep problems median score was 114.82, and CP without sleep problems median score was 207.15, $p=0.355$ ).

\section{DISCUSSION}

This is the first study investigating the level of the GMFCS, sleep problems, and QOL of their parents in Turkish children with CP. In this study, the majority of children in CP group were in GMFCS level V. Sleep problems were found $86.6 \%$ of children with spastic CP. Although there was no difference between the GMFCS scores of the children, sleep problems total scores, and morning fatigue were the primary affected sleep disorder because the majority of children at GMFCS level II and level $V$ were experiencing morning fatigue. There was no difference between cognition, medication use, and sleep problems. Comparing the control group, children with CP showed much more sleep problems based on the CSHQ scores. Parents who had children with CP had worse scores in NHP.

In the study conducted by Romeo et al. (23) abnormal 
sleeping scores was found $13 \%$ of children with $\mathrm{CP}$, and there was at least one abnormal score in sleep questionnaire in $\% 35$. Another study of Romeo et al. (24) found that more than $40 \%$ of children with CP presented with at least one sleep disorder, and there was a relationship between sleep disturbance and GMFCS level V. McCabe et al. (25) argued that several sleep problems exist in each GMFCS level. The children and adolescents with CP were reported to be affected by sleep disorders at any age and every GMFCS level (25). Hemmingsson et al. (6) claimed that sleep problems are even more severe among children in GMFCS level IV and V. Adiga et al. (26) reported that there was no significant correlation between GMFCS levels and sleep disorders. In this study, we found sleep disorders in each GMFCS levels. There is a discrepancy in the literature, regarding GMFCS levels and sleep problems. Some sources argue that those two parameters are related, and some state the opposite. According to the literature, it is not possible to say that sleep disorders are correlated with increased GMFCS levels.

In our study, the only significant difference between GMFCS levels and sleep problems was found in morning fatigue. However, we thought that this was due to the accumulation of the amount of children in level II and V having morning fatigue.

In their study Elsayed et al. included 100 children with CP, aged between 2 and 12 years, and found a high incidence of sleep problems in both preschool and school-age groups. Pre-school children have more prevalence for early insomnia (46.2\%), while school group suffers more sleep-disordered breathing (50\%), more nightmares (50\%), more sleep talking (12.5\%), and more excessive daytime sleepiness (62.5\%) (27). Another study reported that $43.8 \%$ of children with CP, between 6 and 12 years, had sleep problems (1). The most common sleep disorder in both preschool- and school-age children with $\mathrm{CP}$ was problem in the initiation and maintenance of sleep (1). The $44 \%$ of children with $\mathrm{CP}$ had clinically significant symptoms in one or more sleep disorder, notably, 59.5\% were schoolaged children (28). These results and our findings show similarities based on sleep disorders seen in children with $\mathrm{CP}$, However, in this study, we could not make a grouping as preschool children because the minimum age was four years old. This could be one of this study's limitations.

In another study, researchers reported that snoring (9.6\%), insomnia (12.8\%), and sleep-related breathing disorders (18.1\%) were the most common problems in children with CP (4). In this study, sleep disorders of children varied such as snoring (33\%), difficulty in falling into sleep at night (50\%), nightly wakeups (60\%), asking for parent while falling into sleep $(73.3 \%)$, OSA $(21.6 \%)$, resistance to sleep $(41.6 \%)$, restlessness in sleep (56.6\%), and morning fatigue $(41.6 \%)$. In this study, the prevalence of sleep problems was $86.6 \%$ among 60 children with spastic CP and 35\% among 60 typically developing children. Having a physical disorder may affect child's sleep pattern. The relatively higher rates compared to the literature could be attributed to cultural differences between Turkey and the other countries. Sleep advice given to children by their families in Turkey, sleep habits, and various factors affecting sleep should be examined in future studies.

Besides questioning the sleep, we investigated the cognitive function and medication use in children with CP. We could not find any difference between cognition, medication use, and sleep problems. However, we did not ask the parents the kind of medication taking by their children, any possible side effects, dose, and the time of the day of the medication. Since medication could affect child's sleep pattern, the medication use should be investigated in further study in detail. This was another limitation of this study.

Wayte et al. (22) stated that children's sleep disorders were significantly correlated with their mothers' sleep disorders. Mothers of children with CP have a high rate of sleep problems, and their $\mathrm{QOL}$ is highly associated with maternal depression. In this study, we investigated parents' perceived QOL using the NHP. Since taking care of a disabled child all day long is comparable to a full-time job, it must be tiring both physically and mentally. We used this tool since it is easy to apply and easily understood by the participants. Based on the data, the most affected sub-parameters of perceived QOL were found as emotional reactions, social isolation, physical mobility, and energy. Parents in 
the control group showed better NHP scores. The fact that families with disabled children having sleep problems negatively affected their perception of QOL. Further study may assess QOL using more specific questionnaires.

In conclusion, we pointed out that sleep disturbances are critical problems in children with $\mathrm{CP}$, and should be investigated with more comprehensive evaluation tools. Parents and especially mothers, as they are the primary caregivers, undertake a demanding full-time task, no matter how willing they are. Further study is need to investigate the factors related to sleep problems.

\section{Sources of Support: None.}

Conflict of Interest: Authors declare no conflict of interest.

Ethical Approval: The study protocol was approved by Bolu Abant İzzet Baysal University Ethics Committee (Approval Date: 20.12.2012 and Approval Number: 2012/244).

Peer-Review: Externally peer-reviewed.

Author Contributions: Concept - ŞA; Design ŞA; Supervision - ŞA; Resources and Financial Support - DK; Materials - DK; Data Collection and/ or Processing - DK; Analysis and/or Interpretation - ŞA, DK; Literature Research - DK; Writing Manuscript - DK, ŞA; Critical Review - ŞA.

Acknowledgements: The study was performed at Bolu Abant İzzet Baysal University, Faculty of Health Sciences, Department of Physical Therapy and Rehabilitation, Bolu, and Özel Illgim Special Education and Rehabilitation Center, Düzce, Turkey. Authors thank the participants and their families for their co-operation and owners of the rehabilitation centers.

\section{REFERENCES}

1. Newman CJ, O'Regan M, Hensey O. Sleep disorders in children with cerebral palsy. Dev Med Child Neurol. 2006;48(7):564-8.

2. Simard-Tremblay E, Constantin E, Gruber R, Brouillette RT, Shevell M. Sleep in children with cerebral palsy: a review. J Child Neurol. 2011;26(10):1303-10.

3. Zucconi M, Bruni O. Sleep disorders in children with neurologic diseases. Semin Pediatr Neurol. 2001;8(4):258-75.

4. Koyuncu E, Türkkani MH, Sarikaya FG, Özgirgin N. Sleep disordered breathing in children with cerebral palsy. Sleep Med.
2017;30:146-50

5. Tietze A-L, Blankenburg M, Hechler T, Michel E, Koh M, Schlüter $B$, et al. Sleep disturbances in children with multiple disabilities. Sleep Med Rev. 2012;16(2):117-27.

6. Hemmingsson H, Stenhammar A-M, Paulsson K. Sleep problems and the need for parental night-time attention in children with physical disabilities. Child Care Health Dev. 2009;35(1):89-95.

7. Sandella DE, O’Brien LM, Shank LK, Warschausky SA. Sleep and quality of life in children with cerebral palsy. Sleep Med. 2011;12(3):252-6.

8. Gunel MK, Mutlu A. Disability and its relation with functional independence in children with cerebral palsy: an ICF study of preliminary clinical experience from Turkey. Fizyoter Rehabil. 2007;18(3):171-8.

9. Tarsuslu T, Livanelioğlu A. Serebral paralizili bireylerde motor limitasyonun mobilite ve bağımsızlık düzeyi üzerine etkisi. Fizyoter Rehabil. 2008;19(3):117-22.

10. Karaçal Ş. Konya ilinde yaşayan 0-17 yaş grubu çocuklarda uyku bozukluklarının sıklığı. Selçuk Üniversitesi Tıp Fakültesi. Doktora tezi; 2010.

11. Bülbül S, Kurt G, Ünlü E, Kırlı E. Adolesanlarda uyku sorunları ve etkileyen faktörler. Çocuk Sağlığı Hastalık Derg. 2010;53(3):20410.

12. Zuculo GM, Knap CCF, Pinato L. Correlation between sleep and quality of life in cerebral palsy. CoDAS. 2014;26(6):447-56.

13. Fitzgerald DA, Follett J, Van Asperen PP. Assessing and managing lung disease and sleep disordered breathing in children with cerebral palsy. Paediatr Respir Rev. 2009;10(1):18-24.

14. Hagberg B, Hagberg G. The origins of cerebral palsy. In: David TJ, ed. Recent advances in paediatrics XI. Edinburgh: Churchill Livingstone; 1993:p.67-83.

15. Palisano R, Rosenbaum P, Walter S, Russell D, Wood E, Galuppi B. Development and reliability of a system to classify gross motor function in children with cerebral palsy. Dev Med Child Neurol. 1997;39(4):214-23.

16. El Ö, Baydar M, Berk H, Peker Ö, Koşay C, Demiral Y. Interobserver reliability of the Turkish version of the expanded and revised gross motor function classification system. Disabil Rehabil. 2012;34(12):1030-3.

17. Colver A. Study protocol: SPARCLE-a multi-centre European study of the relationship of environment to participation and quality of life in children with cerebral palsy. BMC Public Health. 2006;6(1):105.

18. Owens JA, Spirito A, McGuinn M. The Children's Sleep Habits Questionnaire (CSHQ): psychometric properties of a survey instrument for school-aged children. Sleep. 2000;23(8):104352.

19. Fiş NP, Arman A, Ay P, Topuzoğlu A, Güler AS, Imren SG. The validity and the reliability of Turkish Version of Children's Sleep Habits Questionnaire. Anadolu Psikiyatri Derg. 2010;11(2):15160.

20. Kücükdeveci AA, McKenna SP, Kutlay S, Gürsel Y, Whalley D, Arasil T. The development and psychometric assessment of the Turkish version of the Nottingham Health Profile. Int J Rehabil Res. 2000;23(1):31-8.

21. Hunt SM, McEwen J, McKenna SP. Measuring health status: a new tool for clinicians and epidemiologists. JR Coll Gen Pr. 1985;35(273):185-8.

22. Wayte S, McCaughey E, Holley S, Annaz D, Hill CM. Sleep problems in children with cerebral palsy and their relationship with maternal sleep and depression. Acta Paediatr. 2012;101(6):61823.

23. Romeo DM, Brogna C, Musto E, Baranello G, Pagliano E, Casalino $\mathrm{T}$, et al. Sleep disturbances in pre-school age children with cerebral palsy: a questionnaire study. Sleep Med. 2014;15(9):1089-93.

24. Romeo DM, Brogna C, Quintiliani M, Baranello G, Pagliano E, 
Casalino T, et al. Sleep disorders in children with cerebral palsy: neurodevelopmental and behavioral correlates. Sleep Med. 2014;15(2):213-8.

25. McCabe SM, Blackmore AM, Abbiss CR, Langdon K, Elliott C. Sleep concerns in children and young people with cerebral palsy in their home setting. J Paediatr Child Health. 2015;51(12):118894.

26. Adiga D, Gupta A, Khanna M, Taly AB, Thennarasu K. Sleep disorders in children with cerebral palsy and its correlation with sleep disturbance in primary caregivers and other associated factors. Ann Indian Acad Neurol. 2014;17(4):473.

27. Elsayed RM, Hasanein BM, Sayyah HE, El-Auoty MM, Tharwat $\mathrm{N}$, Belal TM. Sleep assessment of children with cerebral palsy: using validated sleep questionnaire. Ann Indian Acad Neurol. 2013;16(1):62.

28. Horwood L, Mok E, Li P, Oskoui M, Shevell M, Constantin E. Prevalence of sleep problems and sleep-related characteristics in preschool-and school-aged children with cerebral palsy. Sleep Med. 2018;50:1-6. 